ROCZNIKI PEDAGOGICZNE

Tom 11(47), numer 1 - 2019

DOI: http://dx.doi.org/10.18290/rped.2019.11.1-6

\title{
EUGENIUSZ SAKOWICZ
}

\section{W SŁUŻBIE WYCHOWANIA. KS. WINCENTEGO GRANATA „WIZJA” PEDAGOGII ŻYCIA I PEDAGOGIKI KATOLICKIEJ}

Znawczyni życia i dzieła ks. Wincentego Granata oraz długoletnia jego współpracownica Halina Irena Szumił następująco ujmuje pedagogiczną pasję i zaangażowanie jednego z najwybitniejszych polskich teologów XX wieku: „Sługa Boży nie tylko uczył, ale całą swą osobowością, codziennym życiem, podejmowaniem wysiłków naukowych i wychowawczych wpływał na kształtowanie postaw umysłowych i duchowych swych wychowanków. Nadto miał ogromne poczucie odpowiedzialności za formację uczniów w okresie spełniania obowiązków prefekta w szkołach radomskich, później alumnów w Wyższym Seminarium Duchownym w Sandomierzu, a także kapłanów studiujących na Katolickim Uniwersytecie Lubelskim oraz innych wiernych, których spotkał na drodze swego kapłańskiego życia. O tym świadczą wspomnienia i świadectwa wielu z nich.

$\mathrm{Na}$ każdym poziomie nauczania był znakomitym pedagogiem, wychowawcą pozostawiając w umysłach i sercach swych wychowanków niezatarty ślad. Był dobrym znawcą przedmiotu, który wykładał, dobrym nauczycielem, przyjacielem młodzieży, radosnym chrześcijaninem, przedstawicielem Kościoła i nade wszystko świadkiem Chrystusa.

W swoim środowisku promieniował wiedzą, kulturą osobistą, prawością i ogromną życzliwością dla innych. Szedł do ludzi, do ludzkich trosk z prostotą i dostojeństwem człowieka, który innych szanuje, których stara się zrozumieć, których kocha. Zawsze pamiętał o ich potrzebach i spieszył z pomocą. Był człowiekiem niegorszącym się nigdy z nędzy natury ludzkiej, człowiekiem, który mocno wierzy w zwycięstwo w duszy ludzkiej lepszych pierwiastków nad tymi, co w niej są niskie. Żył, jak wierzył i nauczał” (Szumił, 2017a; Szumił, 2012).

Prof. dr hab. EugEnIUSZ SAKOwICZ - Wydział Teologiczny, Uniwersytet Kardynała Stefana Wyszyńskiego w Warszawie; adres do korespondencji - e-mail: eugeniusz.sakowicz@wp.pl 
Ks. Wincentemu Granatowi przysługuje tytuł Sługi Bożego, co oznacza, że jest kandydatem na ołtarze. Celem trwającego procesu kanonicznego, który rozpoczął się 12 VI 1995 r. w diecezji sandomierskiej, jest stwierdzenie heroiczności jego cnót, co wyznacza ważny etap na drodze ku beatyfikacji, następnie - kanonizacji.

\section{KS. WINCENTY GRANAT - DOCTOR HUMANUS}

Wincenty Granat (Szumił, 1985; Szumił, 1993; Szumił, 2010; Szumił, 2012; Szumił, 2012a; Szumił, 2013; Janiec, Tkaczyk, Szumił, 2017) urodził się 1 kwietnia 1900 r. w Ćmielowie k. Ostrowca Świętokrzyskiego w diecezji sandomierskiej. Po ukończeniu w 1918 r. Męskiej Szkoły Filologicznej w Sandomierzu wstąpił tamże do Seminarium Duchownego. Po odbyciu studiów filozoficzno-teologicznych przyjął w 1924 r. święcenia kapłańskie. Skierowany został następnie przez biskupa diecezji sandomierskiej na dalsze studia w prowadzonej przez Towarzystwo Jezusowe uczelni „Gregorianum” w Rzymie. Tamże uzyskał dwa doktoraty: w 1925 r. z filozofii i w 1928 r. z teologii. Niespełnione wcześniejsze pragnienie ks. W. Granata, by zostać jezuitą - tak sądzimy - kształtowało jego życie, jako kapłana i uczonego, czyniącego, zgodnie $\mathrm{z}$ dewizą założyciela jezuitów, św. Ignacego Loyoli, „Wszystko na większą chwałę Bożą” („Omnia ad maiorem Dei gloriam”). Studia w „Gregorianum” nie były zatem przypadkowe. Zresztą - nic w życiu człowieka nie jest przypadkowe, kiedy poddaje się on prowadzeniu Bożej Opatrzności. Głęboko wierzył w tę prawdę przyszły Sługa Boży.

Po powrocie z Włoch do Polski w 1928 r. podjął ks. W. Granat pracę w szkolnictwie w Radomiu. Był tamże w latach: 1928-1929 prefektem w szkole powszechnej, 1930-1933 zaś w szkole średniej (Szumił, 1998). I chociaż w 1933 r. został wykładowcą w Wyższym Seminarium Duchownym w Sandomierzu, to wciąż pełnił obowiązki kierownika duchowego w Liceum Kurii Diecezjalnej w Sandomierzu.

Z Katolickim Uniwersytetem Lubelskim związał się w 1952 r. Rozpoczynał pracę w tej uczelni jako „mąż Boży”, który doświadczył zmagań o godność człowieka w czasie wojny i w okresie ,ppozornego" pokoju w powojennym czasie, „zawłaszczonym” przez ideologię socjalistyczną. Lata 50. i 60. XX w. wyznaczały zakorzenianie się w Polsce obcego polskiemu etosowi narodowemu światopoglądu marksistowsko-leninowskiego. W tym okresie coraz bardziej ujawniało się „spętanie” społeczeństwa polskiego przez ideologię wrogą człowiekowi, Bogu, Chrystusowi i Kościołowi. Na ten właśnie czas przypadło „apogeum” twórczości ks. W. Granata. 
Ks. Wincenty Granat był profesorem KUL, uczelni, której dewizę stanowi hasło: „Deo et Patriae” („Bogu i Ojczyźnie”). W 1965 r. objął urząd rektora tej uczelni. Notabene w tym czasie pracował już w KUL ks. Karol Wojtyła, z którym na pewno ks. W. Granat nie raz się spotykał. Z godności rektora KUL zrezygnował w 1970 r. Zamieszkał wówczas w Opolu Lubelskim nieopodal Lublina, gdzie kontynuował prace pisarskie oraz angażował się w działalność duszpasterską. Od 1933 r. - aż do śmierci - pozostawał w bliskich relacjach ze Zgromadzeniem Sióstr Służek Najświętszej Maryi Panny Niepokalanej (Siostry Służki z Mariówki) (Szumił, 2005).

Dorobek naukowy ks. W. Granata, jego spuścizna teologiczna jest imponująca (Szumił, 2017). Jest on autorem monumentalnego dzieła - Dogmatyka katolicka (t. 1-9, Lublin 1959-1967) oraz dwóch tomów (,jakby streszczenia uzupełnionego przez Sobór Watykański II") tejże Dogmatyki, pt. Ku człowiekowi i Bogu w Chrystusie (t. 1-2, Lublin 1972-1976; wyd. 2, Lublin 2013-2016).

Uczony ten podejmował nie tylko tematy ściśle teologiczne, ale również z zakresu innych nauk, w tym pedagogiki. W swoich dziełach (książkach, artykułach) zwracał uwagę na konieczność uwspółcześnienia teologii (aggiornamento) (Sakowicz, 2006), tak by jej wywód, argumentacje, uzasadnienia nie mijały się z człowiekiem, jego problemami, lecz na nie odpowiadały. Ks. W. Granat wiedział, iż teologia powinna być wrażliwa na to wszystko, co „współczesne” - dzisiejsze, co dotyczy i wiąże się z życiem konkretnego człowieka w okresie, w którym żyje. Refleksja pedagogiczna, prowadzona przez niego jeszcze przed II wojną światową, była jego wkładem w ówczesną dyskusję o roli edukacji i wychowania właśnie w określonym kontekście kulturowo-społecznym i historycznym.

Uczony ten wskazywał na imperatyw dialogu Kościoła katolickiego ze światem takim, jaki jest, nie tylko ze społecznością chrześcijańską, czy kościelnymi wspólnotami, ale i z ludźmi różnych przekonań i światopoglądów. Ta opcja preferencyjna - opcja teologiczna na rzecz człowieka ujawniła się w jego dziełach, których tytuły są wielce wymowne, np.: Osoba ludzka. Próba definicji (Sandomierz 1961); w 2006 r. w Wydawnictwie KUL ukazało się poprawione i rozszerzone wydanie 2 . tej pracy przygotowane przez K. Guzowskiego i H.I. Szumił; U podstaw humanizmu chrześcijańskiego (Poznań 1976) - Wydanie 2. poprawione i przygotowane przez K. Guzowskiego i H.I. Szumił zostało opublikowane w 2007 r. w Wydawnictwie KUL pt. Fenomen człowieka. U podstaw humanizmu chrześcijańskiego. Po śmierci ks. Wincentego Granata wydana została jego książka pt. Personalizm chrześcijański. Teologia osoby ludzkiej (Poznań 1985). Aktualnie przygotowywane jest drugie wydanie tej publikacji. 
W dorobku encyklopedycznym (leksykograficznym) rektora KUL znalazły się hasła (artykuły encyklopedyczne) zamieszczone w Encyklopedii Katolickiej, m.in. Antropologia teologiczna (Granat, 1973), Ateizm (Granat, 1973a), Bóg (Granat, 1976, 1976a). Podkreślmy mocno, to właśnie osoba ludzka, widziana w perspektywie teologicznej, wyznaczała oś jego prac naukowo-badawczych i dydaktyki. Człowiek był centrum jego pedagogii i pedagogiki.

Cechą charakterystyczną teologii ks. W. Granata - jak stwierdził jego uczeń, abp Alfons Nossol - był ,personalistyczny humanizm, antropologiczno-chrystologiczne uwspółcześnienie teologii oraz nurt pastoralno-kerygmatyczny" (Hryniewicz, Nossol, 1972). Te nurty oddziaływały na pedagogię i pedagogikę ks. W. Granata.

Ks. W. Granat był pedagogiem i dydaktykiem mającym wielkie doświadczenie zdobyte w pracy na różnych stanowiskach w szkolnictwie i w ogóle oświacie. Ogromny dorobek naukowy oraz praca nauczycielska, w której prowadzenie był zaangażowany, jest świadectwem jego niepodważalnych kompetencji oraz niekwestionowanego autorytetu (Janiec, 2012). Jako kapłan, profesor, nauczyciel akademicki, pisarz oraz rektor KUL głosił prawdę, której źródłem i celem jest Bóg. Był „nauczycielem chrześcijańskiej doktryny i jej realizatorem" (Szumił, 1983). Z racji wybitnych osiągnięć naukowych, idących w parze ze skromnością i pokorą, obdarzony został tytułem Doctor humanus. Zmarł 11 grudnia 1979 r. w Sandomierzu.

\section{PEDAGOGIA ŻYCIA}

Imperatywem pedagogii życia ks. W. Granata było: ,prawdę czynić w miłości” (zob. Ef 4,15) (Sakowicz, 2018). W życiu Sługi Bożego zbiegły się właściwie dwie pedagogie życia - jego osobista, własna, $\mathrm{z}$ tą zaproponowaną dla innych. Między jedną a drugą nie było sprzeczności, dysonansu, dysharmonii. Ich fundamentem była wiara, rozumiana jako „całkowite” (według abp. Alfonsa Nossola „totalne”) „dążenie osoby ludzkiej, z Chrystusem, do Ojca dokonujące się w Duchu Świętym” (Nossol, 1993a, kol. 39).

Doctor humanus wskazywał na dogmaty chrześcijańskiej wiary (w tym wcielenie Jezusa Chrystusa) ,wyznaczające" fundament humanizmu oraz personalizmu chrześcijańskiego. Pedagogia, czerpiąc wzorzec z prawdy o wcieleniu Syna Bożego, służyć ma wyzwoleniu człowieka zarówno z duchowego, jak i materialnego zła. Przekonywał, iż ludzie wierzący nie tyle idą $\mathrm{z}$ Jezusem 
Chrystusem, ile w Nim chodzą. Pan Jezus nie jest zatem wobec człowieka Pedagogiem ,zewnętrznym”, lecz „,wewnętrznym” Nauczycielem - Mistrzem duchowym. Nie poucza On z zewnątrz, lecz mówi do człowieka w jego sumieniu, sercu, myśli.

Pedagogię życia cechuje otwartość. Człowiek wychowywany przez innych, ale również i przez siebie, powinien podejmować nieustanny trud otwierania się na Boga, a także coraz większego uwrażliwiania się na to, co ludzkie. Imperatywem ma tu być przykazanie miłości Boga i bliźniego.

Życie człowieka wierzącego kształtuje się we wspólnocie Kościoła. Znamienne są słowa, które wypowiedział ks. W. Granat w dniu 8 XII 1979 r. - trzy dni przed śmiercią: „Od dzieciństwa, wszystko, co robiłem, chciałem czynić dla Boga i Kościoła” (Szumił, 2012, s. 3). „Pedagogia” opatrzona rzeczownikiem „życia” nie może być (i nie jest) oderwana od życia wiarą, od środowiska, w którym się ona rodzi i rozwija. Jest nim właśnie wspólnota ludzi wierzących w Boga, czyli osoby związane szczególnymi więzami duchowej jedności, stanowiące Kościół.

Spoiwo tejże pedagogii, której można też przydać nazwę ,pedagogii Bożej w życiu człowieka” stanowiła Biblia - „Chrystus napisany”. Uzasadnienia biblijne, argumentacje i wyjaśnienia skrypturystyczne były kluczem do rozwiązywania wszelkich dylematów, problemów, zawiłości ludzkiej egzystencji. Bóg Najwyższa Prawda, podkreślał ks. Wincenty Granat, jest „osobowym życiem” (Nossol, 1993, kol. 39).

Dogmat - przekazywał ks. W. Granat - „z życia Bożego pochodzi i o życiu ludzkim mówi" (Granat, 1960, s. 138; Nossol, 1984, s. 260). Pedagogia życia człowieka zatem wywodzi się i promieniuje z życia Boga w Trójcy Jedynego. Wierzący jest w relacji do żywego Boga, a nie Jego idei, wyobrażenia, czy w ogóle teologicznej koncepcji. Pozostaje w odniesieniu do Wszechmogącego, który objawił się człowiekowi i ludzkości jako Osoba. Imperatywem tej pedagogii było powtórzmy - ,prawdę czynić w miłości” (Nossol, 1993, kol. 39). Czynienie prawdy jest wysiłkiem, trudem związanym z cierpieniem, ofiarą. Rozumiał to i doświadczał Doctor humanus i dlatego nauczanie jego było wiarygodne.

Ks. W. Granat wskazywał na dogmat wcielenia jako rację godności człowieka oraz fundament humanizmu chrześcijańskiego oraz personalizmu. W Jezusie Chrystusie - wcielonym Bogu-Człowieku - każdy człowiek jako osoba oraz wspólnota ludzi dąży ku ostatecznemu spełnieniu się, ku zbawieniu. Skupienie się na Jezusie Chrystusie, postawienie Go w samym centrum wszelkich „spraw” człowieka teologia określa jako chrystocentryzm. Nie jest on antytezą antropologii. Skoncentrowanie się na Panu Jezusie pozwala przezwyciężyć, pokonać błędną alternatywę: „Bóg albo człowiek”. Opowiedzenie się za Bogiem z równoczesnym 
pominięciem drugiego człowieka prowadzi do utopii spirytyzmu. Skoncentrowanie się natomiast na człowieku i zanegowanie Boga, odrzucenie Go wiedzie do materializmu, ostatecznie zaś do reifikacji, urzeczowienia człowieka. Z nim, jako przedmiotem, wszystko można „zrobić”, czemu ks. W. Granat mocno się sprzeciwiał.

Pedagogia życia, czerpiąc wzorzec z prawdy o wcieleniu Syna Bożego, służy uważał ks. W. Granat - wyzwoleniu człowieka nie tylko z duchowego, ale też i materialnego zła, z grzechu (Granat, 1939). Inkarnacja Boża - podkreślał wskazuje na wartość, wyjątkowość, niepowtarzalność każdej bez wyjątku osoby.

Kościół, jako środowisko życia człowieka wierzącego, wychowującego siebie i innych ku pełni miary Ewangelii, nie stanowi - przekonywał ks. W. Granat instytucji tylko ludzkiej. Jako Mistyczne Ciało Chrystusa oraz jednocześnie jako Lud Boży jest ,przedłużeniem Chrystusa w przestrzeni i czasie” (Nossol, 1993, kol. 40). Podkreślał nie raz, iż Chrystus to Kościół, a Kościół to Chrystus. Ta mistyczna i realistyczna prawda była zawsze skutecznym remedium na ataki tych, którzy - posłuszni nieludzkim i jednocześnie antyludzkim ideologiom oraz kierowani przez nie - podejmowali działania na rzecz zniszczenia Kościoła.

\section{PEDAGOGIKA KATOLICKA - DIAKONIA WYCHOWANIA}

Ks. W. Granat, zainspirowany ogłoszoną 31 XII 1929 r. przez papieża Piusa XI encykliką Divini illius magistri o prawach i obowiązkach wychowawczych rodziny, Kościoła i państwa wobec dzieci i młodzieży (uważana jest ona za jeden z najważniejszych papieskich dokumentów traktujących o nauczaniu i wychowaniu chrześcijańskim), opracował kilka artykułów z zakresu pedagogiki oraz dydaktyki. Na podstawie analizy tych tekstów można naszkicować zarys jego teorii wychowawczej, której fundament wyznacza światopogląd chrześcijański (Wierna, 2017).

Opublikowane przez niego w wydawanym we Włocławku „Ateneum Kapłańskim” oraz ukazującym się we Lwowie „Miesięczniku Katechetycznym i Wychowawczym” artykuły stanowiły jego „głos” w dyskusji na temat polskiej oświaty i szkolnictwa, która to wymiana poglądów była żywa w całym okresie dwudziestolecia międzywojennego. Profesja nauczyciela traktowana była wówczas z najwyższą atencją przez cale społeczeństwo, odbudowujące polską tożsamość po okresie zniewolenia przez zaborców. Nauczyciel jako urzędnik państwowy podejmował pracę jak ,,misjonarz”, udając się - w duchu posłuszeństwa 
władzom oświatowym - np. z Krakowa do szkół na Pomorzu. Bywało i tak, że Wielkopolanin wyruszał na wioski Wileńszczyzny, by tam prowadzić nauczanie.

Teksty ks. W. Granata były ważnym wówczas argumentem na rzecz roli pedagogiki religijnej w procesie odbudowy polskości przez edukację i na drodze wychowania młodego pokolenia (Granat, 1935; Granat, 1935a; Perzanowska, 2004). Celem wychowania chrześcijańskiego, prowadzonego przez rodzinę, Kościół i szkołę ma być ukształtowanie prawdziwego chrześcijanina i jednocześnie dobrego obywatela. Te podmioty wychowawcze nie mogą ze sobą konkurować, lecz ich działalność pedagogiczna winna być komplementarna.

Nie ma teorii wychowawczej, która byłaby neutralna. U podstaw każdego teoretycznego wyjaśniania świata i jego złożoności sytuują się określone przekonania. Cel i zadania oraz przedmiot i metody wychowania wypływają i czerpią motywację z światopoglądu, który - według ks. W. Granata - stanowi zbiór zasad oraz pojęć o świecie i jego naturze, a także o początku i celu oraz o człowieku w nim „obecnym” (Granat, 1939). W optyce chrześcijańskiej światopogląd obejmuje antropologię, czy wręcz nią jest. Chrześcijańska wizja życia - zauważał ks. W. Granat - podkreśla rangę natury człowieka i jego powołania życiowego. W jej centrum sytuuje się natomiast prawda o Bogu i człowieku. Prawda jest „osią” wszystkich wartości.

Światopogląd katolicki motywowany jest z jednej strony prawdą objawioną przez Boga oraz z drugiej - prawdą rozumową. Człowiek na drodze refleksji prowadzonej przez rozum może dojść do poznania istnienia Boga. To przekonanie ks. W. Granata miało mocne posadowienie w Nowym Testamencie (Rz 1,20). Człowiek - odczytując w świecie ślady Objawienia Bożego - angażuje swój rozum. Prawdy wiary i prawdy rozumu nie mogą być zatem antagonizowane, przeciwstawiane. Jako prawdy komplementarne wyznaczają teorię oraz pragmatykę pedagogiczną. W takim spojrzeniu na objawienie Boże ujawniało się przekonanie ks. W. Granata o racjonalności wiary. Według niego „Natura i łaska, ziemia i niebo, samoistność człowieka i zależność od praw moralnych, jednostka i grupa społeczna, statyzm zasadniczych pierwiastków w człowieku (ciało i dusza), a równocześnie rozwój i wolność woli, konieczność praw biologicznych, wielkość człowieka i jego nędza moralna, pokora i duma, a przede wszystkim niezwykła godność syna Bożego - oto są elementy, z których personalizm i humanizm katolicki buduje harmonijnie swój światopogląd" (Granat, 2016, s. 86-87; Wierna, 2017).

Pedagogika katolicka - uważał ks. W. Granat - winna być w służbie wychowania. Jej zadaniem było przeciwstawienie się pedagogicznym nurtom laickim negującym duchowy wymiar człowieka i w konsekwencji tego redukcjonizmu 
koncentrującym się tylko na tym, co materialne. Ks. W. Granat wiedział, iż naturalizm pedagogiczny, krytycznie oceniony przez encyklikę Divini illius magistri, negował skutki grzechu pierworodnego. Celem wychowania - według tego dokumentu - ma być przywrócenie upadłego człowieka (na skutek tego grzechu) do godności dziecka Bożego (Nowaczyk, 1979). Myśl ta głęboko była obecna w poglądach pedagogicznych ks. W. Granata.

W Sensus catholicus czytamy: „[Należy] zebrać wszystkie siły, skupić się w sobie, przeliczyć wartości, dotrzeć do fundamentalnych katolickich założeń, jasno skrystalizować cel wychowania - takie byłyby zadania współczesnej pedagogiki religijnej" (Granat, 1934, s. 242)). Słowa te ujawniają głęboki realizm uczonego. Pedagog nie może tylko „ułamkiem” swoich sił służyć wychowankowi, lecz winien być całkowicie jemu oddany. „Skupienie się w sobie” to postulat zintegrowania sfer osobowości, gdzie intelekt nie przeciwstawiałby się woli, a emocje nie władałyby jednym i drugim. „Przeliczanie wartości” wiąże się z odniesieniem do aksjologii, w której każda wartość ma swoje właściwe miejsce, a wszystkie podporządkowane są wartości najwyższej - Bogu. Fundamentalne natomiast założenia katolicyzmu są od wieków niezmienne. Wskazują one na niezbywalną wartość każdej osoby, której godność proklamował i zawsze bronił Jezus Chrystus.

Proces wychowania młodego pokolenia dopomina się o męstwo wychowawców. Katoliccy nauczyciele, pedagodzy winni nade wszystko być odważnymi i rozsądnymi świadkami Jezusa Chrystusa - Mistrza i Nauczyciela. Odważny pedagog powinien zawsze kierować się bojaźnią Bożą, czyli pokorą będącą świadomością prawdy o sobie samym.

Ks. W. Granat zadawał przed wielu laty pytanie, które i dziś nie straciło (i zapewne nie straci w przyszłości) swego dramatyzmu: „Dlaczego z nadprzyrodzonością i chrześcijańskim charakterem wychowania mielibyśmy się kryć? [...] Dlaczego w katolickiej pedagogice nie możemy postawić wyraziście celu wychowania katolickiego?" (Granat, 1934, s. 254). U źródeł teorii pedagogicznej, inspirowanej chrystianizmem, sytuuje się ewangeliczna odwaga.

Renata Wierna, analizując cechy osobowości katolickiej - kształtowanej według ks. W. Granata w procesie wychowania - zauważyła jej elementy: wewnętrzny dynamizm, optymizm i radość, solidaryzm, indywidualizm (Wierna, 2017). Składowe te budują harmonijną osobowość wychowanka.

O wewnętrznym dynamizmie wychowania stanowi cel ostateczny życia człowieka. To on - finalny punkt egzystencji nadaje sens każdej chwili życia ludzkiego, każdemu wydarzeniu, w ogóle losowi. Eschatologia stanowi zatem 
skuteczne antidotum wobec egzystencjalnej desperacji, zniechęcenia, przygnębienia. Wiara w „rzeczy ostateczne” przyczynia się do pokonania pesymizmu. Chrześcijanin podejmować ma zatem - uważał ks. W. Granat - nie tylko trud pracy nad sobą, ale jednocześnie nad udoskonaleniem świata. Do dynamizmu myśli i działań motywować go ma prawda akcentowana przez ks. W. Granata, według której „Chrystus jest życiem, a nie biernością” (Granat, 1934, s. 258). Skoro tak, to naśladowcy Jezusa Chrystusa nie mogą ulegać zniechęceniu. Nie mogą poddawać się przeciwnościom losu.

Optymizm chrześcijański wyraża się na różne sposoby, m.in. przez radość. Źródłem pełnego ufności i spokoju przeżywania wydarzeń życiowych w duchu radości jest Jezus Chrystus, który przez mękę i śmierć na krzyżu pokonał zło, a zatem unicestwił pesymizm. Przez zmartwychwstanie potwierdził walor ludzkiego życia przeznaczonego do wiecznej chwały - do zbawienia. Chrześcijanin, głęboko wierzący w Bożą Opatrzność, nie będzie w obliczu konfrontacji z przeciwnościami losu poddawał się zwątpieniu czy rezygnacji. Nie może to być, jak cytuje R. Wierna słowa ks. W. Granata, kiedy podejmuje refleksję nad jego myślą pedagogiczną: „,nie ten płytki i tani [optymizm], oparty na wierze w technikę, lecz głęboki, bo sięgający najskrytszych tajników duszy, gdzie Bóg z człowiekiem się łączy" (Granat, 1936, s. 338).

Ks. W. Granat postrzegał człowieka zgodnie z antropologią chrześcijańską jako jedność duchowo-psycho-fizyczną. I właśnie tak widziany człowiek ma być podmiotem wychowania. Pedagogika katolicka zatem występować winna przeciwko wszelkim redukcjonizmom, okradającym człowieka z jego bogactwa osobowego. Harmonijność osoby wskazuje - jak zaznaczał ks. W. Granat - na gotycką katedrę, ,gdzie każdy ornament istnieje w całości i przez całość, a ponad martwym kamieniem góruje ożywiająca go myśl chwały Bożej [...]" (Granat, 1935a).

Zgodnie z założeniami solidaryzmu (ukształtowanego w 2. połowie XIX w.) - który ks. W. Granat poznał w okresie międzywojennym i w którym to czasie o nim pisał - istnieć powinna wspólnota interesów różnych grup i warstw społecznych. Odwołując się do tego kierunku społeczno-politycznego wskazywał na konieczność „współgrania” doczesności i wieczności, które nie mogą z sobą walczyć, czy też sobie zaprzeczać. Chrześcijanin nie pędzi bowiem życia jako samotnik bądź pustelnik. Związany jest zawsze z określonym społeczeństwem, które kształtuje jego tożsamość. Będąc zanurzonym w życiu publicznym, jednocześnie jest uczestnikiem życia duchowego. Pomostem między jedną a drugą sferą, obszarem życia jest Kościół zawsze solidarny z człowiekiem. Wspólnota 
ludzi wierzących potrafi w sposób twórczy łączyć to, co doczesne z tym, co wieczne (Perzanowska, 2004).

„Wychowanie katolickie wcale nie zmierza do tego - podkreślał w dziele Katolicki ideat wychowawczy - aby kształcić fanatyków, którzy poza kręgiem swego wyznania nie zobaczą nic szlachetnego" (Granat, 1936). Formuje ono osobę odpowiedzialną za siebie, za drugiego człowieka, za naród, za Kościół.

„Ku człowiekowi i Bogu w Chrystusie” to nie tylko podana przez ks. W. Granata definicja teologii, ale też i pedagogii Bożej oraz pedagogiki religijnej.

\section{BIBLIOGRAFIA}

Bielecki, S. (2006). Znaki czasu. W: R. KAmiŃski, W. PrZYgoda, M. FiaŁkowski (red.), Leksykon teologii pastoralnej (s. 923-926). Lublin: Towarzystwo Naukowe KUL.

FrejdASz L. (2013). Sługa Boży. W: Encyklopedia Katolicka, 18, kol. 414. Lublin: Towarzystwo Naukowe KUL.

Granat, W. (1933). Aktualizacja w nauczaniu religii. Miesięcznik Katechetyczny i Wychowawczy, $22,115-121$.

GranAt, W. (1973). Antropologia. V. Antropologia teologiczna. C. Antropologia systematyczna. W: Encyklopedia Katolicka, 1, kol. 698-702. Lublin: Towarzystwo Naukowe KUL.

GranAT, W. (1973a). Ateizm. W: Encyklopedia Katolicka, 1, kol. 1030-1040. Lublin: Towarzystwo Naukowe KUL.

Granat, W. (1976). Bóg. V. W dziejach teologii. B. W orzeczeniach Kościoła. W: Encyklopedia Katolicka, 2 kol. 938-942. Lublin: Towarzystwo Naukowe KUL.

GranAt, W. (1976a), Bóg. VI. W teologii systematycznej. B. Transcendencja i immanencja Boga. W: Encyklopedia Katolicka, 2, kol. 949-953. Lublin: Towarzystwo Naukowe KUL.

Granat, W. (2014). Deo et Patriae. Gtos rektora KUL (red. H.I. Szumił) (s. 57-240). Lublin: Towarzystwo Naukowe KUL.

Granat, W. (1960). Dogmatyka katolicka. T. 4: Chrystus Odkupiciel i Kościót - Jego Mistyczne Ciało, Lublin: Towarzystwo Naukowe KUL.

Granat, W. (1936). Katolicki ideał wychowawczy. Miesięcznik Katechetyczny i Wychowawczy, $25(8), 325-338$.

Granat, W. (1948). Nauczanie teologii dogmatycznej w seminariach duchownych jako funkcja wychowania. Polonia Sacra, 1 (3-4), 339-343.

Granat, W. (2016). O katolickim życiu w świetle nauki o tasce (oprac. H. I. Szumił). Sandomierz: Wydawnictwo Diecezjalne i Drukarnia w Sandomierzu.

Granat, W. (2008). Panie, szukam Twego oblicza. Wybór pism (oprac. i przygotowanie do druku H.I. Szumił przy współpracy K. Guzowskiego). Lublin-Sandomierz: Wydawnictwo Diecezjalne i Drukarnia w Sandomierzu. 
Granat, W. (1935). Podstawy niekatolickiej i katolickiej dydaktyki. Ateneum Kapłańskie, 21(35), 455-473.

Granat, W. (1935a). Podstawy niekatolickiej i katolickiej dydaktyki. Ateneum Kaptańskie, 21(36), 136-149.

Granat, W. (1934). Sensus catholicus. Miesięcznik Katechetyczny i Wychowawczy, 23(6-7), 241258.

GRANAT, W. (1939). Zasady pedagogiki katolickiej w świetle dogmatu Odkupienia i grzechu pierworodnego. Miesięcznik Katechetyczny i Wychowawczy, 28, 26-53.

Granat, W. (1984). Wybór pism ks. Wincentego Granata (przygotowała do wydania H.I. Szumił). Warszawa: Akademia Teologii Katolickiej.

Guzowski, K., Szumit, H.I. (2007). Fenomen człowieka. U podstaw humanizmu chrześcijańskiego. Lublin: Wydawnictwo KUL.

Hryniewicz, W., Nossol, A. (1972). Profesor Wincenty Granat. Roczniki Teologiczno-Kanoniczne, $19(2), 5-9$.

JANIEC, Z. (2012). Sługa Boży Wincenty Granat (1900-1979) jako dydaktyk i pedagog., Kronika Diecezji Sandomierskiej, 105(3-4), 230-236.

Janiec, Z., TкасZYк, M., Szumit H.I. (2017). Ksiadz Wincenty Granat. Rektor Katolickiego Uniwersytetu Lubelskiego - kandydat do chwaty ottarzy. Lublin: Towarzystwo Naukowe KUL.

Nossol, A. (1993). Granat Wincenty. W: Encyklopedia Katolicka, 6, kol. 40. Lublin: Towarzystwo Naukowe KUL.

Nossol, A. (1993a). Granat Wincenty, 2. Poglądy teologiczne. W: Encyklopedia Katolicka, 6, kol. 39. Lublin: Towarzystwo Naukowe KUL.

Nossol, A. (1981). Systematyczne spojrzenie na teologię ks. prof. W. Granata. Studia Sandomierskie, 2, 31-34.

Nossol, A. (1984). Teologia bliższa życiu. Wptyw teologii na egzystencję chrześcijańska. Opole: Wydawnictwo Św. Krzyża.

NowaCZYK, J. (1979). Divini Illius Magistri. W: Encyklopedia Katolicka, 3, kol. 1350. Lublin: Towarzystwo Naukowe KUL.

PerZANOwSKA, A. (2004). Wzór osobowy katechety-wychowawcy w ujęciu Sługi Bożego ks. Wincentego Granata. Studia Sandomierskie, 11(2), 93-97.

Sakowicz, E. (2006), Aggiornamento. W: R. Kamiński, W. Przygoda, M. FiaŁkowski (red.), Leksykon teologii pastoralnej (s. 32-36). Lublin: Towarzystwo Naukowe KUL.

SAKowicz, E. (2018). Pedagogia życia Sługi Bożego ks. Wincentego Granata (1900-1979) - rektora Katolickiego Uniwersytetu Lubelskiego. W: A. KRÓLIKOwSKA, J. FALKOWSKA (red.), Nauczyciele. Szkice portretów uczonych i nauczycieli (s. 57-73). Kraków: Wydawnictwo Naukowe Akademii Ignatianum w Krakowie.

Szumit, H.I. (2013). Człowiek wiary. Stuga Boży ks. Wincenty Granat. Sandomierz: Wydawnictwo Diecezjalne i Drukarnia w Sandomierzu.

Szumit, H.I. (1993). Granat Wincenty. 1. Życie i dzieła. W: Encyklopedia Katolicka, 6, kol. 38-39. Towarzystwo Naukowe KUL.

Szumit, H.I. (1993a). Granat Wincenty. [Bibliografia]. W: Encyklopedia Katolicka, 6, kol. 40. Lublin: Towarzystwo Naukowe KUL.

Szumit, H.I. (1998). Działalność sługi Bożego ks. Wincentego Granata na terenie Radomia w latach 1928-1933, 1938-1939. Kronika Diecezji Radomskiej, 7(3-4), 275-294.

SzUMIŁ, H.I. (1983). Ksiądz Wincenty Granat nauczyciel chrześcijańskiej doktryny i jej realizator (19001979). W: B. BeJZE (red.), Chrześcijanie, 11 (s. 9-193). Warszawa: Akademia Teologii Katolickiej.

Szumit, H.I. (2017). Profesor i Mistrz. Stuga Boży ks. Wincenty Granat. Lublin: Towarzystwo Naukowe KUL. 
Szumit, H.I (2010). Przez prawdę do miłości. Stuga Boży ks. Wincenty Granat (1900-1979). Sandomierz: Wydawnictwo Diecezjalne i Drukarnia w Sandomierzu.

SzumiŁ, H.I. (2017a). [Stuga Boży nie tylko uczyt], mps.

Szumit, H.I. (red.) (2012). Dla Boga i Kościoła. Stuga Boży ks. Wincenty Granat - świadectwa. Sandomierz: Wydawnictwo Diecezjalne i Drukarnia w Sandomierzu.

Szumit, H.I. (2012a), Żył, jak wierzył i nauczał. Sługa Boży ks. Wincenty Granat (1900-1979). W: G. BARTOSZEwsKi (red.), Święci sq wśród nas (s. 183-216). Warszawa: Oficyna Wydawniczo-Poligraficzna „Adam”.

Szumit, H.I. (red.) (2005). Pozostat w nas żywy. Kontakty Stugi Bożego ks. Wincentego Granata ze Zgromadzeniem Sióstr Stużek NMP Niepokalanej. Sandomierz: Wydawnictwo Diecezjalne i Drukarnia w Sandomierzu.

Szumit H.I. (red.) (1985). Tajemnica człowieka. Wokót osoby i myśli ks. Wincentego Granata. Lublin: Towarzystwo Naukowe KUL.

WIERNA, R. (2000). Ideał katechety-wychowawcy w okresie międzywojennym w pismach ks. Wincentego Granata. Kronika Diecezji Radomskiej, 9, 429-434.

WIERNA R. (2009). Wpływ encykliki „Divini illius magistri” na wizerunek katechety-wychowawcy w ujęciu ks. Wincentego Granata. W: G. BARTOSZEWSKI (red.), W stużbie stowa pisanego (s. 543550). Lublin-Sandomierz: Wydawnictwo Diecezjalne i Drukarnia w Sandomierzu.

WIERNA R. (2017). Światopogląd podstawą teorii wychowawczych w ujęciu sługi Bożego ks. Wincentego Granata, mps.

\title{
W SŁUŻBIE WYCHOWANIA. KS. WINCENTEGO GRANATA „WIZJA” PEDAGOGII ŻYCIA I PEDAGOGIKI KATOLICKIEJ
}

\author{
Streszczenie
}

Ks. Wincenty Granat (1900-1979) jako kapłan, profesor, nauczyciel akademicki, pisarz oraz rektor Katolickiego Uniwersytetu Lubelskiego (1965-1970) głosił „słowem, piórem i życiem Prawdę w miłości”. Z racji wybitnych osiągnięć naukowych w zakresie teologii, idących w parze ze skromnością i pokorą, obdarzony został tytułem Doctor humanus. Cechą charakterystyczną teologii ks. W. Granata był personalistyczny humanizm oraz wymiar antropologiczno-chrystologiczny, nadto pragmatyzm duszpasterski.

Imperatywem pedagogii życia ks. W. Granata było: „prawdę czynić w miłości” (por. Ef 4,15). Przekonywał, iż ludzie wierzący nie tyle idą z Jezusem Chrystusem, ile „w Nim chodzą”. Pan Jezus nie jest zatem wobec człowieka Pedagogiem ,zewnętrznym”, lecz „wewnętrznym” Nauczycielem Mistrzem duchowym. Pedagogię tę cechuje otwartość. Człowiek wychowywany przez innych, ale również i przez siebie, powinien podejmować nieustanny trud otwierania się na Boga, a także coraz większego uwrażliwiania się na to, co ludzkie.

Pedagogika katolicka powinna być w służbie człowieka. Ks. W. Granat podkreślał rolę pedagogiki religijnej w procesie odbudowy polskości. Celem edukacji i wychowania młodego pokolenia jest przeciwstawienie się pedagogicznym nurtom laickim negującym duchowy wymiar człowieka. $\mathrm{O}$ wewnętrznym dynamizmie wychowania stanowi cel ostateczny życia człowieka (tj. eschatologia), który nadaje sens każdej chwili życia ludzkiego. Wychowanie katolickie formuje osobę odpowiedzialną za siebie, za drugiego człowieka, za naród, za Kościół. „Ku człowiekowi i Bogu w Chrystusie" to nie tylko podana przez ks. W. Granata definicja teologii, ale też i pedagogii Bożej oraz pedagogiki.

Słowa kluczowe: Ks. Wincenty Granat; Doctor humanus; pedagogia życia; pedagogika katolicka; wychowanie. 


\title{
IN THE SERVICE OF UPBRINGING. THE REVEREND WINCENTY GRANAT'S VISION OF PEDAGOGY OF LIFE AND CATHOLIC PEDAGOGY
}

\author{
S u m m a r y
}

As a priest, professor, academic teacher, writer and Rector of John Paul II Catholic University of Lublin (1965-1970), the Reverend Wincenty Granat (1900-1979) preached "Truth in love with the spoken and written word and with his life." In recognition of his outstanding scholarly achievements in theology, coupled with his modesty and humility, he was awarded the title Doctor Humanus. Granat's theology is characterised by personalist humanism, the anthropological and Christological dimension as well as pastoral pragmatism.

"To do truth in love" was the imperative of the pedagogy of life according to the Rev. Wincenty Granat (cf. Ephesians: 4:15). He argued that believers do not merely walk with Jesus Christ but they walk in Him. Thus, Jesus is man's "internal" rather than "external" Pedagogue; a Teacher and spiritual Master. This pedagogy is characterised by openness. Brought up by others as well as oneself, an individual should make a constant effort to be open to God and be more sensitive to what is human.

Catholic Pedagogy should serve the people. Rev. Granat emphasised the role of religious pedagogy in the process of rebuilding Polishness after the time of the Partitions and war. In his opinion, the goal of education and upbringing of the young generation was to counter lay pedagogical ideas that negated the spiritual dimension of man. The inner dynamics of upbringing is determined by the ultimate goal of human life (i.e. eschatology) that gives meaning to every moment of our life. Catholic upbringing forms individuals who take responsibility for themselves, other people, the nation, the Church. "Towards man and God in Christ" is Rev. Granat's definition of not only theology but also Divine upbringing and pedagogy.

Key words: the Reverend Wincenty Granat; Doctor Humanus; the pedagogy of life; Catholic pedagogy; upbringing. 